the patient's ethnic origin, her visit to an endemic region three and a half years before, and the eosinophilia. The diagnosis was confirmed by finding $S$ mansoni ova in the rectal biopsy specimen and the raised schistosomal enzyme linked immunosorbent assay antibody titre. Stool examination for parasites is helpful in early cases of schistosomiasis, but rectal biopsy is usually more definitive, particularly in chronic cases. Rapid cure with oxamniquine, a specific schistosomicidal drug, ${ }^{3}$ added further support to the diagnosis. In other reports the diagnosis has been established from spinal cord specimens obtained at operation or necropsy. ${ }^{1}$

Spinal cord disease is usually caused by $S$ mansoni or $S$ haematobium, whereas $S$ japonicum has a predilection for the brain. ${ }^{1}$ Various clinical syndromes have been described, ${ }^{2}$ including intramedullary granuloma, which was probably responsible for the disease in our patient. Ova may be deposited without an immediate inflammatory reaction but become the nidus for a chronic granulomatous lesion which may manifest years after the initial migration. ${ }^{4}$ Transverse myelitis, the commonest manifestation, ${ }^{2}$ is thought to be due to a vasculitis with subsequent infarction in the spinal cord. Parasitic invasion of the spinal theca may result in myelopathy or radiculopathy. Ova deposition evoking no response is also well recognised. The predilection of $S$ mansoni and $S$ haematobium infections for the lower thoracic and lumbar spinal cord is probably due to the free anastomosis between pelvic veins and the valveless vertebral venous plexus.

What distinguishes this case from all others reported is that the diagnosis was made without resorting to surgery and oxamniquine rapidly and effectively produced a cure. Until recently the most efficacious treatments for schistosomiasis were compounds containing antimony, which were used in conjunction with corticosteroids to reduce any inflammatory reaction. ${ }^{4}{ }^{5}$ Oxamniquine kills male worms and prevents the females from laying their eggs, and in our patient probably the sudden cessation of ova deposition in the spinal cord was responsible for allowing the intramedullary granuloma to shrink. We suggest that oxamniquine, one of the drugs of choice for $S$ mansoni infections, ${ }^{3}$ should be tried as early as possible in patients with schistosomiasis affecting the spinal cord, as this drug may be curative and avoid the need for surgical decompression.

1 Wakefield GS, Carroll JD, Speed DE. Schistosomiasis of the spinal cord. Brain 1962;85:535-52.

${ }^{2}$ Herskowitz A. Spinal cord involvement with Schistosoma mansoni. I Neurosurg 1972 ;36:494-8.

${ }^{3}$ Favid Z, Watten RH. Schistosomiasis. Medicine International 1981 ; $1: 70-3$.

- Budzilovich GN, Most N, Feigin I. Pathogenesis and latency of spinal cord schistosomiasis. Archives of Pathology 1964;77:383-8.

5 Bird A. Acute spinal schistosomiasis. Neurology (Minneap) 1964;14: 647-56.

(Accepted 2 February 1984)

Department of Medicine, University College Hospital, London WC1E 6AU

JOHN EFTHIMIOU, BSC, MRCP, honorary lecturer

DAVID DENNING, MRCP, registrar

Correspondence to: Dr John Efthimiou.

\section{Salicylate intoxication in the elderly due to benorylate}

An 82 year old woman developed salicylate intoxication after treatment with benorylate, which is metabolised to salicylic acid and paracetamol. Her serum salicylate concentrations were compared with those in five other elderly patients given benorylate.

\section{Case reports}

INITIAL CASE

An alert 82 year old woman (case 1 in the table) was admitted to hospital with restricted mobility due to painful osteoarthritis of the hips and knees. She also had quiescent Crohn's colitis and a history of cardiac failure and had had a left cerebral infarct 12 years previously. On admission she had a haemoglobin concentration of $10.6 \mathrm{~g} / \mathrm{dl}$, which was attributed to her Crohn's colitis, and a blood urea concentration of $8.7 \mathrm{mmol} / 1(52.3 \mathrm{mg} / 100 \mathrm{ml})$. She was taking digoxin $250 \mu \mathrm{g}$ daily, frusemide $40 \mathrm{mg}$ daily, and potassium supplements for cardiac failure, with prednisolone enema $20 \mathrm{mg}$ daily and sulphasalazine $2 \mathrm{~g}$ daily for Crohn's disease.
In hospital benorylate suspension $5 \mathrm{ml}(2 \mathrm{~g})$ four times daily was started for her osteoarthritis. Eight days later she became restless and agitated, and on the following day she became confused and had visual hallucinations. On examination she was not feverish but was flushed and dehydrated and had considerable tachypnoea. Her haemoglobin concentration was $10.3 \mathrm{~g} / \mathrm{dl}$ and leucocyte count $4.9 \times 10^{9} / 1$, and serum concentrations were: urea $18.5 \mathrm{mmol} / \mathrm{l}(112 \mathrm{mg} / 100 \mathrm{ml})$, sodium $144 \mathrm{mmol}(\mathrm{mEq}) / 1$, potassium $4.2 \mathrm{mmol}$ $(\mathrm{mEq}) / 1$, total carbon dioxide $12 \mathrm{mmol}(\mathrm{mEq}) / \mathrm{l}$, chloride $100 \mathrm{mmol}(\mathrm{mEq}) / 1$ total protein $73 \mathrm{~g} / 1(7 \cdot 3 \mathrm{~g} / 100 \mathrm{ml})$, and glucose $4 \cdot 7 \mathrm{mmol} / 1(85 \mathrm{mg} / 100 \mathrm{ml})$. The $\mathrm{pH}$ of her arterial blood was $7 \cdot 43$, oxygen partial pressure $12.9 \mathrm{kPa}(97 \mathrm{~mm} \mathrm{Hg})$, carbon dioxide partial pressure $2.5 \mathrm{kPa}(19 \mathrm{~mm} \mathrm{Hg})$, base excess $-7.3 \mathrm{mmol}$ $(\mathrm{mEq}) / 1$, and standard bicarbonate concentration $18.5 \mathrm{mmol} / \mathrm{l}$. A serum salicylate concentration of $3.06 \mathrm{mmol} / 1(42.5 \mathrm{mg} / 100 \mathrm{ml})$ measured by Trinder's method ${ }^{1}$ confirmed the diagnosis of salicylate intoxication with a compensated metabolic acidosis and increased anion gap. The benorylate and sulphasalazine were stopped and she was given $500 \mathrm{ml}$ lactate $0 \cdot 16 \mathrm{~mol} / \mathrm{l}$ intravenously over eight hours followed by isotonic dextrose. Her clinical condition and results of biochemical tests returned to normal within 24 hours.

Sulphasalazine was restarted, and serum salicylate concentrations remained negligible $(<0.12 \mathrm{mmol} / 1(1.7 \mathrm{mg} / 100 \mathrm{ml}))$. Subsequently benorylate suspension was added to her treatment at a dose of $2.5 \mathrm{ml}(1 \mathrm{~g})$ four times daily. The mean of four serum salicylate concentrations obtained before each dose of benorylate after eight days of treatment was $1.85 \mathrm{mmol} / 1$ $(25.7 \mathrm{mg} / 100 \mathrm{ml})$. Serum paracetamol concentrations were less than $0.06 \mathrm{mmol} / 1(1 \mathrm{mg} / 100 \mathrm{ml})$. On the 10th day she developed a mild recurrence of visual hallucinations and confusion, and these again resolved after benorylate was stopped.

\section{OTHER PATIENTS STUDIED}

We subsequently studied the effects of benorylate in five female hospital inpatients who yielded normal results to liver function tests. After they had given informed consent they were prescribed benorylate suspension $2.5 \mathrm{ml}(1 \mathrm{~g})$ four times daily. The table shows the mean serum salicylate concentrations in these five patients (cases 2-6) and the index case on the eighth day of treatment.

Results after treatment with benorylate for eight days

\begin{tabular}{ccccccc}
\hline $\begin{array}{c}\text { Case } \\
\text { No }\end{array}$ & $\begin{array}{c}\text { Age } \\
\text { (years) }\end{array}$ & $\begin{array}{c}\text { Weight } \\
(\mathbf{k g})\end{array}$ & $\begin{array}{c}\text { Blood } \\
\text { urea } \\
(\mathrm{mmol} / \mathrm{l})\end{array}$ & $\begin{array}{c}\text { Serum } \\
\text { creatinine } \\
(\mu \mathrm{mol} / \mathrm{l})\end{array}$ & $\begin{array}{c}\text { Glomerular } \\
\text { filtration } \\
\text { rate } \\
(\mathrm{ml} / \mathrm{minute})\end{array}$ & $\begin{array}{c}\text { Mean } \\
\text { serum } \\
\text { salicylate } \\
(\mathrm{mmol} / \mathrm{l})\end{array}$ \\
\hline 1 & 82 & 50 & $9 \cdot 7$ & 114 & 43 & 1.85 \\
2 & 79 & 63 & $7 \cdot 0$ & 74 & 38 & 1.66 \\
3 & 79 & 47 & 6.1 & 128 & 26 & 1.56 \\
4 & 90 & 69 & 11.2 & 98 & 24 & 1.21 \\
5 & 79 & 48 & $10 \cdot 0$ & 104 & 33 & 1.05 \\
6 & 77 & 78 & 6.5 & 79 & 56 & 0.75 \\
\hline
\end{tabular}

Conversion: SI to traditional units-Urea: $1 \mathrm{mmol} / \mathrm{l} \approx 6 \mathrm{mg} / 100 \mathrm{ml}$. Creatinine: Conversion: SI to traditional units-Urea: $1 \mathrm{mmol} / \mathrm{l} \approx 6 \mathrm{mg} / 100$
$1 \mathrm{~mol} / \mathrm{l} \approx 11.3 \mathrm{\mu g} / 100 \mathrm{ml}$. Salicylate: $1 \mathrm{mmol} / 1 \approx 13.9 \mathrm{mg} / 100 \mathrm{ml}$.

\section{Comment}

Benorylate was the drug responsible for the salicylate intoxication in the patient described, as administration of sulphasalazine alone did not result in appreciable serum concentrations of salicylate. The five patients studied subsequently achieved a wide range of mean serum salicylate concentrations, which in two cases were as high as in the initial case. This variable response, which has been reported previously, ${ }^{2}$ did not appear to be related to renal function or body weight. The mean of all serum salicylate concentrations in the five patients studied, who were given $4 \mathrm{~g}$ benorylate daily, was $1.25 \mathrm{mmol} / \mathrm{l}$ $(17.4 \mathrm{mg} / 100 \mathrm{ml})$. This is similar to the mean plasma salicylate concentration of $1.26 \mathrm{mmol} / 1(17.5 \mathrm{mg} / 100 \mathrm{ml})$ found in a study of 11 men and 13 women (median age 51) prescribed a mean daily dose of $11.26 \mathrm{~g}$ benorylate. ${ }^{3}$ These findings suggest that the metabolism or excretion, or both, of benorylate occurs at a slower rate in elderly women, although wide individual variation seems to occur.

Benorylate is absorbed unchanged and hydrolysed rapidly to salicylic acid and paracetamol in the intestine and circulation. After further hepatic metabolism it is excreted principally as urinary metabolites of salicylic acid and paracetamol. Hence impaired renal function, common in elderly people, may result in high serum concentrations of salicylate due to reduced excretion.

The administration of more than $4 \mathrm{~g}$ benorylate daily in the elderly carries a disproportionately high risk of salicylate intoxication as the serum salicylate concentration is not related to dose. ${ }^{4}$ In older patients salicylate intoxication may present atypically, diagnosis is often delayed, and mortality is high. ${ }^{5}$ We conclude that the maximum dose of benorylate in the elderly should be $4 \mathrm{~g}$ daily, serum salicylate concentrations should be monitored, and the manufacturer's literature should be amended to state this. 
I thank Professor $\mathrm{R} W$ Stout for permission to report this case and for his helpful advice.

1 Trinder P. Rapid determination of salicylate in biological fluids. Biochem $\mathfrak{f}$ 1954;57:301-3.

2 Aylward M. Toxicity of benorylate. Br Med 7 1973;iii:347-8.

${ }^{3}$ Champion GD, Day RO, Paull PD, et al. Clinical pharmacology and efficacy of benorylate in patients with rheumatoid arthritis. Aust NZ f Med 1978;8:22-8.

${ }^{4}$ Bender KJ. Salicylate intoxication. Drug Intell Clin Pharm 1975;9: 350-60.

' Anderson RJ, Potts DE, Gabow PA, Rumack BH, Schrier RW. Unrecognised adult salicylate intoxication. Ann Intern Med 1976;85: 745-8.

(Accepted 8 February 1984)

Department of Geriatric Medicine, Queen's University of Belfast and Belfast City Hospital, Belfast BT9 7BL

T R O BERINGER, MRCP, MRCPT, senior registrar

\section{Hypercalcaemia during resolution of calcinosis in juvenile dermatomyositis}

Calcinosis is common in juvenile dermatomyositis and may regress spontaneously. We report a case of juvenile dermatomyositis in which regression of pelvic calcinosis was associated with life threatening hypercalcaemia.

\section{Case report}

An 11 year old white boy was diagnosed as having dermatomyositis when he presented with proximal muscle weakness, a heliotrope rash, and a scaly dermatitis on the extensor aspect of his knuckles. Muscle enzyme activities were raised (serum creatine phosphokinase activity $331 \mathrm{U} / \mathrm{l}$ (normal 5-115 U/1)), and electromyographic findings were consistent with myopathy. He was treated with prednisone with good effect but required increasing doses after several relapses over the subsequent seven years.

In November 1980, at the age of 17, he sustained a minor blow to his left thigh and shortly after noted a painful lump in his left groin. Radiography showed calcinosis in the soft tissues around the left hip and thigh. This became more extensive over the next three months with resulting restriction in the movement of his hip. He developed anaemia and thrombocytosis; the erythrocyte sedimentation rate was $30 \mathrm{~mm}$ in the first hour and serum creatine phosphokinase activity $215 \mathrm{U} / \mathrm{l}$. Serum calcium and parathyroid hormone concentrations were not raised. In February 1981 the lump in his groin became fluctuant, and about $100 \mathrm{ml}$ of turbid material flecked with calcium was drained surgically, leaving a chronic sinus and severe residual calcinosis.

In January 1982 he developed a fever, vomiting, and malaise together with a tender swelling over his left buttock. Serum calcium concentration was $3.1 \mathrm{mmol} / 1(12 \mathrm{mg} / 100 \mathrm{ml}$ ) (normal $2 \cdot 07-2.52 \mathrm{mmol} / 1(8 \cdot 3-10 \mathrm{mg}$ ) $100 \mathrm{ml})$ ), serum phosphate concentration $1.59 \mathrm{mmol} / 1(4.9 \mathrm{mg} / 100 \mathrm{ml})$ (normal 0.9-1.6 mmol/1 $(2 \cdot 8-5 \mathrm{mg} / 100 \mathrm{ml}$ )), and serum albumin concentration $31 \mathrm{~g} / \mathrm{l}$. The urine calcium concentration was $6.6 \mathrm{mmol}(265 \mathrm{mg}) / 24 \mathrm{~h}$ (normal $1 \cdot 2-6 \cdot 2 \mathrm{mmol}(48-248 \mathrm{mg}) / 24 \mathrm{~h}$ ), serum parathyroid hormone concentration less than $0.05 \mu \mathrm{g} / \mathrm{l}$ (normal $0 \cdot 1-0.35 \mu \mathrm{g} / 1$ ), and serum 1,25dihydroxycholecalciferol concentration $24 \mathrm{pmol} / \mathrm{l}$ (10 ng/l) (normal 70$132 \mathrm{pmol} / 1(29-55 \mathrm{ng} / \mathrm{l}))$. He was treated with saline diuresis and increased doses of prednisone, but his serum calcium concentration remained raised.

Three weeks later, after complaining of weakness, nausea, constipation, and aching in the jaw, he had several grand mal convulsions and then remained unconscious. Serum calcium concentration was $3.53 \mathrm{mmol} / \mathrm{l}$ $(14 \mathrm{mg} / 100 \mathrm{ml})$ and serum magnesium concentration $0.6 \mathrm{mmol} / 1(1.5 \mathrm{mg})$ $100 \mathrm{ml}$ ) (normal $0 \cdot 7-1.4 \mathrm{mmol} / 1(1 \cdot 7-3.4 \mathrm{mg} / 100 \mathrm{ml}$ )). A computed tomogram of the brain was normal, but electroencephalography showed a severe abnormality over both cerebral hemispheres. He was treated with saline diuresis, phenytoin, and prednisone $100 \mathrm{mg}$ daily. After 36 hours he awoke suddenly, and over the next few days he recovered fully, although his serum calcium concentration remained raised at $2 \cdot 6-3 \cdot 2 \mathrm{mmol} / 1(10 \cdot 4-12 \cdot 8 \mathrm{mg}$ $100 \mathrm{ml}$ ). Acute hypercalciuria of up to $30 \mathrm{mmol}(1 \cdot 2 \mathrm{~g}) / 24 \mathrm{~h}$ was noted together with phosphaturia (index of phosphate excretion +0.45 (normal -0.3 to +0.3$)$ ), but urine hydroxyproline excretion was low at $0.08 \mathrm{mmol}$ $(10.5 \mathrm{mg}) / 24 \mathrm{~h}$ (normal $0-0.38 \mathrm{mmol}(50 \mathrm{mg}) / 24 \mathrm{~h}$ ), indicating that calcium was not being mobilised from bone.

Treatment was started with aminohydroxypropylidenediphosphonate $10 \mathrm{mg} / \mathrm{kg} /$ day. After one month, during which he remained well, the area of inflammation over his left buttock ulcerated and discharged large amounts of calcific material. The serum calcium concentration rose to $4.1 \mathrm{mmol} / \mathrm{l}$
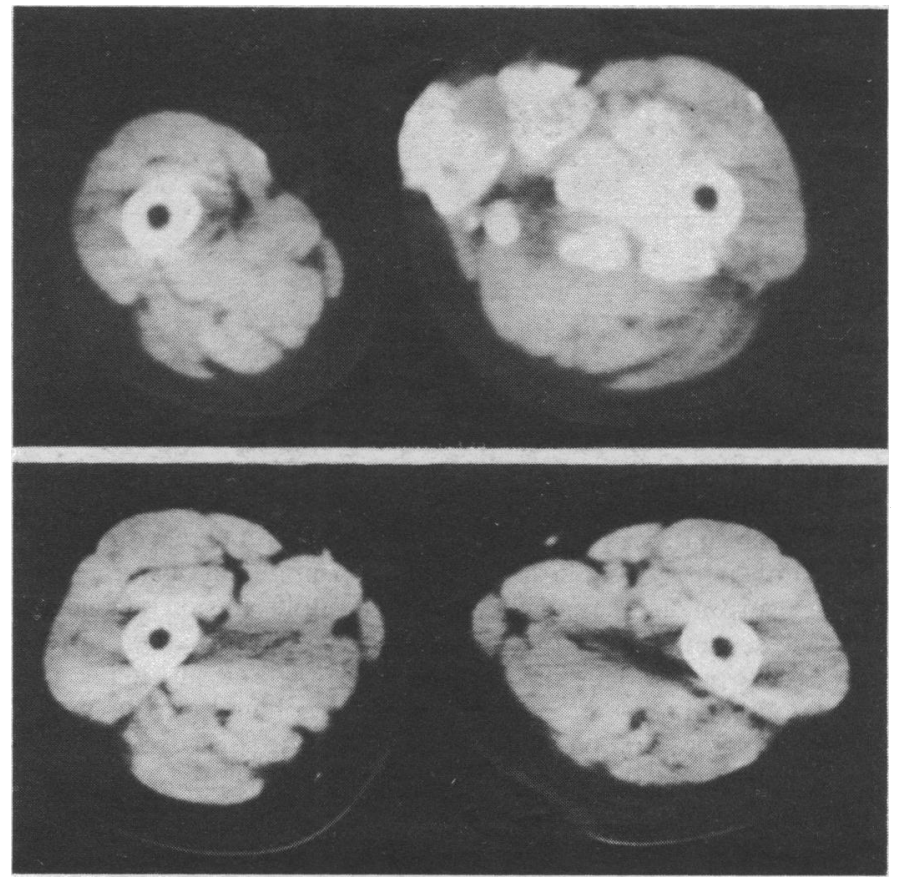

Top: Computed tomogram obtained in February 1981, showing extensive deposits of calcium density in extensor and adductor muscles of left thigh, extending to affect subcutaneous fat (adjacent unaffected thigh muscles are hypertrophied). Bottom: Computed tomogram obtained in March 1983, showing complete reabsorption of calcification; muscles in thigh are normal size.

$(16.4 \mathrm{mg} / 100 \mathrm{ml})$ but fell to $2.9 \mathrm{mmol} / 1(11.6 \mathrm{mg} / 100 \mathrm{ml})$ with saline diuresis. The ulcer continued to drain for two days, discharging roughly $400 \mathrm{ml}$, and then gradually healed with appreciable reduction in the swelling around the hip together with radiological evidence of regression of the calcinosis (figure). Subsequently he remained well with complete clinical and radiological regression of the calcinosis and normal serum calcium and parathyroid hormone concentrations. Steroids were gradually withdrawn. He showed no further evidence of dermatomyositis and achieved full puberty.

\section{Comment}

Calcinosis has an estimated incidence of up to $74 \%$ in patients who survive the active phase of juvenile dermatomyositis. ${ }^{1}$ Episodes of skin ulceration with extrusion of calcific debris are common and may be associated with cellulitis and systemic reaction, as in our patient. Spontaneous regression of calcinosis has been well documented, ${ }^{2}$ but associated hypercalcaemia has not previously been described. In our patient the suppressed serum parathyroid hormone concentration and low vitamin $\mathrm{D}$ and urine hydroxyproline concentrations together with extreme hypercalciuria and phosphaturia suggest that the hypercalcaemia developed as a result of spontaneous mobilisation of calcium from the calcific mass in the pelvis. Treatment with aminohydroxypropylidenediphosphonate did not appear to affect the serum calcium concentration and probably did not influence the outcome.

Professor C Alexander kindly reviewed the radiological findings in this report. The study was supported by a grant from the New Zealand Medical Research Council.

${ }^{1}$ Muller SA, Winklemann RK, Brunsting LA. Calcinosis in dermatomyositis. Arch Dermatol 1959;79:669-72.

2 Sewell JR, Liyanage B, Ansell BM. Calcinosis in juvenile dermatomyositis. Skeletal Radiol $1978 ; 3: 137-43$.

(Accepted 8 February 1984)

Department of Medicine, Auckland Hospital, Auckland, New Zealand

M L WILSHER, MB, CHB, medical registrar

I M HOLDAWAY, MD, FRACP, endocrinologist

J D K NORTH, FRACP, FRCP, professor of medicine

Correspondence to: Dr $M$ Wilsher. 